\title{
A method to develop energy activated ETICS
}

\author{
Simo Ilomets ${ }^{1, *}$, Dariusz Heim ${ }^{2}$, Ivan Chodak $^{3}$, Dariusz Czarny ${ }^{4}$, and Targo Kalamees ${ }^{1}$ \\ ${ }^{1}$ Tallinn University of Technology, Estonia \\ ${ }^{2}$ Lodz University of Technology, Poland \\ ${ }^{3}$ Polymer Institute of the Slovak Academy of Sciences, Slovakia \\ ${ }^{4}$ Sto Sp. z o.o, Poland
}

\begin{abstract}
We propose a method for developing an Energy Activated External Thermal Insulation Composite System (En-ActivETICS) for smart building envelopes that guarantees the required performance, durability, and service life of the building. The En-ActivETICS combines the traditional ETICS with phase change material (PCM) and flexible photovoltaics (FPV). These combined materials will become multifunctional, playing the roles of thermal insulator, heat accumulator, and energy generator with PCM lowering the temperature of FPV and therefore, increasing their efficiency. The En-ActivETICS is a new step in the development of building facade technology enabling to achieve a component that is classified as a functional material. The main result reported in the paper is the proposed method, which improves the existing technical approval guidelines for ETICS, entitled ETAG 004, when thermally activated components are added to the system. The method proposes research activities necessary to determine whether the novel wall system is in line with the essential requirements set to a building by the Construction Products Regulation. When tested according to the proposed method, a wall system should be comprehensively tested and technically documented active thermal insulation system that is aimed to give better building performance in terms of indoor environment, energy efficiency, and aesthetics.
\end{abstract}

\section{Introduction}

It is widely recognised that the building sector accounts for almost $40 \%$ of the global energy consumption, simultaneously playing the key role in achieving the energy efficiency improvement targets. During the last 20 years many efforts have been made to limit $\mathrm{CO}_{2}$ emissions and use of fossil fuels by pushing the building sector to sustainable development. According to the guidelines of the International Energy Agency [1] and requirements of the Energy Performance of Building Directive (EPBD [2]), future buildings should be much more energy efficient than the existing ones. Building design is strongly focused on the improvement of the thermal insulation of the building components, which will lead to a decrease of energy demand as well as onsite production of renewable energy. In renovating the existing apartment buildings the decrease of heating energy is one of the most important needs [3-5]. Comparison of heat loss requirements for building envelopes of nearly zero energy buildings (nZEB) and deep renovation in six European countries showed that the thermal transmittance of the external walls of nZEB should be $5 \%$ of the pre-renovation thermal transmittance in Latvia, $10 \%$ in Estonia, and up to $50 \%$ in Portugal [6].

The external thermal insulation composite system (ETICS) is a widely used facade solution for new buildings $[7,8]$ as well as for renovation $[9,10]$ because its cost is relatively low and it does not require additional foundation owing to its very low weight. In general, ETICS performs quite well in cold and moderate climates when the detailing of joints and openings is well done [11]. Nevertheless, numerous cases exist where the ETICS has degraded too quickly. Liisma et al. [12] showed that most of the defects with ETICS relate to material rupture or material gaps in the finishing coat. The investigation by Kvande et al. [13] clearly show that ETICS is particularly vulnerable when exposed to severe driving rain. A common problem for ETICS is a crack in plaster, which can result, among others, from the following circumstances: instability of the system due to poor fixation to the support; render preparation and atmospheric conditions; displacement of the start and side profiles; application of render between the insulation plates; differences in the base coat thickness; insufficient thickness to warp the reinforcing mesh; misplaced reinforcing mesh; lack of double reinforcement mesh in the window openings and mesh connections; absence of disconnection with building elements; use of dark colours [14].

A characteristic feature of nZEB is a low heat loss of the building envelope. In addition, the building must produce energy on site from renewable sources in order to fulfil compulsory nearly zero energy criteria. Therefore, instead of using a small roof, a facade with its

\footnotetext{
* Corresponding author: simo.ilomets@ $@$ taltech.ee
} 
larger area might be worth consideration for installing renewable energy production elements, such as photovoltaic (PV) panels. Such an approach leads to the possibility of improving the thermal performance of the building envelope by activating the opaque building surfaces to produce electricity.

According to the solar facades review by Quesada et al. [15], three types of active opaque solar facades can be distinguished: building-integrated solar thermal (BIST), building-integrated photovoltaic (BIPV), and buildingintegrated photovoltaic thermal (BIPV/T) systems, see Fig. 1.

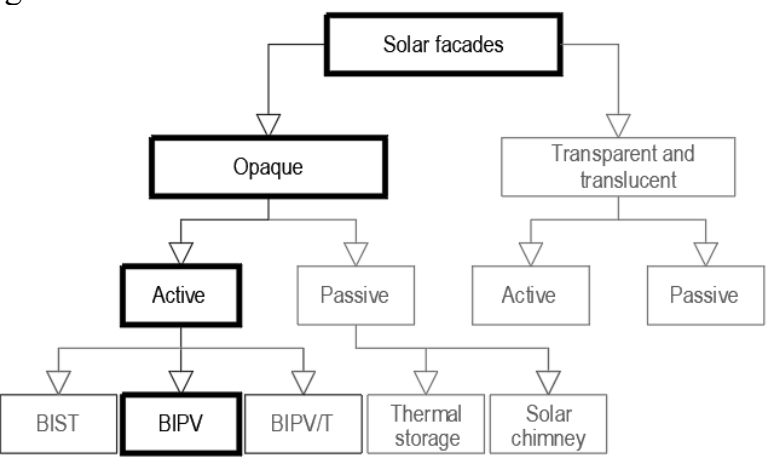

Fig. 1. Building integrated photovoltaic (BIPV) system in a classification of solar facade systems [15]. Bold boxes refer to facades that the current research focuses on.

Development of new, cost effective technologies to integrate flexible photovoltaics (FPV) with ETICS is a research challenge for current and future applications in the case of new buildings as well as renovation leading to the reduction of primary energy use. The existing technical approval guidelines for ETICS, entitled ETAG 004 [16], need to be improved in order to take into account the influence of thermally activated components that are added to the system.

\section{Concept of En-activETICS}

The need for the Energy Activated External Thermal Insulation Composite System (En-ActivETICS) concept comes from the global aim to reduce $\mathrm{CO}_{2}$ emissions in the building sector as well as the need to improve buildings performance, mainly their indoor environment, energy performance, and aesthetics. Concerning prefabricated concrete large panel and brick apartment buildings in Estonia, renovation need of building envelopes was proven by Ilomets [17], which means that millions of square metres of building facades must be covered with affordable thermal insulation in years to come. As the building stocks, but also the climates, in a region are rather similar, extensive energy renovation can be predicted also elsewhere in the same region, proven by activities already carried out and policies adopted.

One of the future trends in building materials development is activation of opaque facades to achieve hybrid materials [18] with changeable conductivity and isothermal storage of heat. Insulation components can be activated in two ways: by an external actuator or automatically. The proposed En-ActivETICS - integration of thermal storage and PV technology within the smart envelope for energy-efficient buildings belongs to the second group of components (automatic activation) and can formally be ranked to the group of smart and active composite materials. The concept is expected to be realised as a functional building component with alternate and self-regulating physical properties and on-site energy production.

The idea how to develop a smart self-regulated energy active building envelope component is based on the combination of ETICS with a phase change material (PCM) and flexible photovoltaic (FPV) cells. A PCM is a substance that has the ability to store and release a large amount of energy during the phase transition. The process is semi-isothermal which results in periodical stabilisation of the medium at a designed temperature level.

Although utilisation of selected types of PCM (mainly paraffin) is not new in the building sector, the proposed solution opens new possibilities for using the features of this product. The initial research work was conducted and the theoretical concept was theoretically proved by Heim and Wieprzkowicz [19]. The main idea is to modify the thermal insulation layer of the wall by a thin film region with a substantially increased heat capacity. By the proper determination of the phase change temperature range as well as total heat capacity, it is possible to increase the FPV cell efficiency and to reduce the total heat flux through the whole component during a particular period of time. For the heating season it can be a period of significant temperature differences between the external and the internal environment (e.g. in the night hours) while during the cooling period it can be a time of substantial heat gains (e.g. during the sunny days). Such inbuilt layer built within the insulation material considerably improves the final energy performance by stimulating the heat flux and reducing the heat balance as well as enhancing the generation of electrical energy. Schematic comparison of the building envelope system of a typical ETICS and the proposed novel En-ActivETICS (applicable for both masonry and concrete as well as new buildings and renovation) is presented in Fig. 2, see also visualisation in Fig. 3.

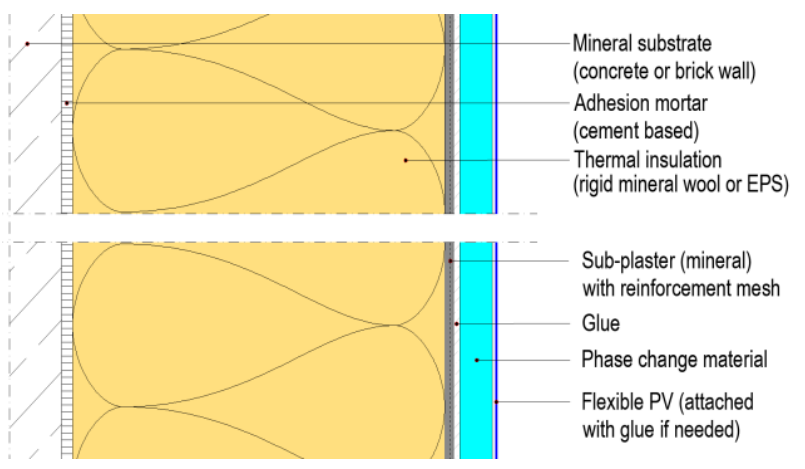

Fig. 1. Vertical cross-section of a proposed novel EnActivETICS concept. 


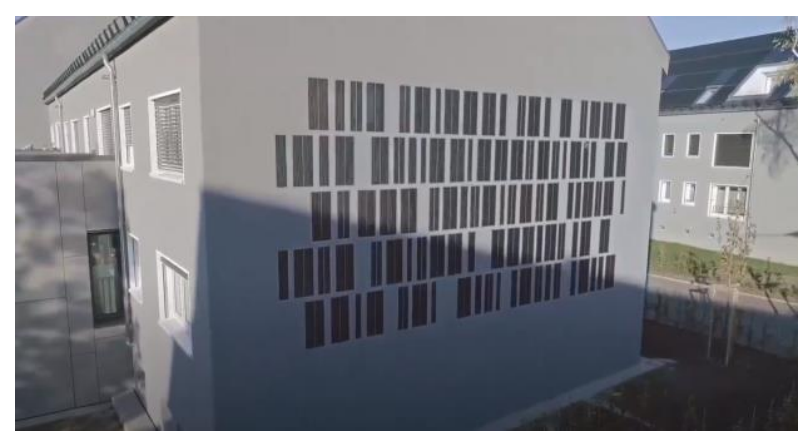

Fig. 2. Visual example of energy activated facade by Opvius $\mathrm{GmbH}$ (bottom).

As FPV elements at the exterior side of the wall are vapour tight, drying out the moisture must be considered. In the current concept, small vertical drainage channels in a range of $10 \mathrm{~mm} \times 10 \mathrm{~mm}$ behind FPV panels are proposed. Channels enable draining out the condensate as well as outward vapour diffusion.

Solid state-of-the-art and Strength, Weakness, Opportunity, and Threat (SWOT) analyses of building integrated solar envelope systems (30 in total) on at least Technology Readiness Level 4 (TRL 4) are presented in [1], but none of them considers ETICS or its modifications. The majority of solar facade technologies are classified as ventilated facades but one existing technology that can be used in combination with nonventilated facade such as ETICS is solar thermal ultrahigh performance concrete [20].

A SWOT analysis method was used during brainstorming in order to analyse En-ActivETICS concept's strengths, weaknesses, opportunities, and threats; results can be seen in Fig. 4.

\begin{tabular}{|c|c|}
\hline Strenghts & Weaknesses \\
\hline $\begin{array}{l}\text { - Relatively low cost } \\
\text { - Synergy of combining PV and PCM } \\
\text { - Decrease of both heating and cooling } \\
\text { need of a building } \\
\text { - Multifunctional use of a system (thermal } \\
\text { insulation, thermal storage, energy } \\
\text { generator) } \\
\text { - Relatively low additional weight on the } \\
\text { wall (in case of EPS thermal insulation } \\
\text { and flexible PV) } \\
\text { - Material effective way of using PCM } \\
\text { - Independancy on extreme temperatures } \\
\text { (no freezing or vapourizing liquids) } \\
\text { - No need for lifting devices (e.g. crane) } \\
\text { on site, all materials and components } \\
\text { placeable by a worker } \\
\text { - Contribution to the global aim to reduce } \\
\text { the consumption of fossil fuels with an } \\
\text { increase of using renewable sources }\end{array}$ & $\begin{array}{l}\text { - Hygrothermal performance due to single } \\
\text { layer weather protection without diffusion } \\
\text { nor air gap behind PV (or PCM) } \\
\text { - Not very robust system, quality is heavily } \\
\text { depending on workmanship quality on site } \\
\text { - Relatively low electricity production of a } \\
\text { flexible PV at } 90 \text { degree inclination, } \\
\text { especially in a midday during spring and } \\
\text { summer } \\
\text { - Lower electricity production in lower parts } \\
\text { of a building due to shading (other } \\
\text { buildings, trees, etc) } \\
\text { - Complexity of mounting on site at desired } \\
\text { quality level } \\
\text { - Creates different facades in south and } \\
\text { north direction }\end{array}$ \\
\hline Opportunities & Threats \\
\hline $\begin{array}{l}\text { - Level of modularity and prefabrication } \\
\text { - Applicable in case of new buildings and } \\
\text { renovation } \\
\text { - Creates new, aesthetic architecture } \\
\text { - Possibility of producing more electricity } \\
\text { compared to PV panel on the roof in } \\
\text { case of large buildings } \\
\text { - Selling electricity back to grid } \\
\text { - Increases daylight between the } \\
\text { buildings in high density districs due to } \\
\text { reflection of the sun from PV } \\
\text { - To boost building capacity due to } \\
\text { improved accessibility of the materials } \\
\text { (scale effect) } \\
\text { - Smaller dependency on electricity grid } \\
\text { in case of electricity storage } \\
\text { - Lowers the peak loads of electricity grid }\end{array}$ & $\begin{array}{l}\text { - Cracks (different materials, different solar } \\
\text { absorption due to colour, many different } \\
\text { joints) } \\
\text { - Moisture safety in case of wooden frame } \\
\text { external wall } \\
\text { - No mechanical fixing of layers outside of } \\
\text { thermal insulation (glue only) } \\
\text { - Electrical components (including plug-in } \\
\text { connections) very close to outdoor } \\
\text { environment (risk of short-circuit, durability) } \\
\text { - Glare effect on neightbouring buildings due } \\
\text { to reflection of the sun from PV } \\
\text { - Performance in case of fire (especially in } \\
\text { case of EPS thermal insulation) }\end{array}$ \\
\hline
\end{tabular}

Fig. 4. Results of SWOT analysis regarding the initial concept of En-ActivETICS.
The study on practical applications of FPV in buildings is a relatively new issue. The benefits of the application of FPV to elements of the building envelope that are exposed to solar radiation are self-evident. The installation of thermal insulation on one side of the PV layer, proposed in the concept, will cause a significant reduction of convective heat transfer; however, latent heat accumulation by PCM will balance those effects. Basic investigation and tests of PCM as a latent storage layer and FPV as an external layer of the building envelope (TRL 1) have already been done, and results of those investigations are published in [21].

Application of FPV as an external finishing of the ETICS instead of rendering is a novel approach that will allow on-site energy production. Moreover, it is also an answer to the need of modern design and aesthetic facades. Furthermore, such a solution will transform the BIPV market from a niche activity to a potential mass market in the future.

\section{Testing the performance durability of En-ActivETICS}

\subsection{Gap with the existing ETAG 004 guideline}

The ETAG 004 Guideline [16] sets out the performance requirements for ETICS used as an external insulation system of building walls made of masonry or concrete. The verification method examines various aspects of performance and gives the assessment criteria to judge the performance for the intended use and the presumed conditions for the design and execution. The ETAG 004 Guideline is for insulation systems with rendering applied directly to the insulating panels, without any air gap or disconnecting layer.

The ETAG 004 Guideline does not cover the following cases:

- ETICS using other facings such as brick slips or tiles;

- ETICS where the rendering is not applied directly to the insulating panels or has an air gap or a disconnecting layer;

- ETICS where the connection between the rendering and insulation product has an additional function in their behaviour.

As En-ActivETICS is covered with FPV instead of rendering and the first prototype of En-ActivETICS concept [21] requires a drainage layer and/or vapour diffusion gaps on the external side of insulation, it is necessary to adapt test methods and Essential Requirements (ER, see Table 1) defined in the Construction Products Regulation [22] for this type of systems. Requirements on ER1 - mechanical resistance and stability (En-ActivETICS is a non-loadbearing building part) and ER5 - protection against noise (PCM and FPV have irrelevant effect on acoustical and sound insulation properties) are out of the scope of the current paper because there are no major differences between ETICS and En-ActivETICS concerning these requirements. 
Table 1. Relationship between characteristics of ER from the Construction Products Regulation and verification method for the En-ActivETICS or components.

\begin{tabular}{|c|c|c|}
\hline ER & Characteristic & Verification method \\
\hline 2 & $\begin{array}{l}\text { - Generation and spread } \\
\text { of fire and smoke } \\
\text { - Safety of occupants and } \\
\text { rescue teams }\end{array}$ & - Reaction to fire \\
\hline 3 & $\begin{array}{l}\text { - Moisture proofing from } \\
\text { outside damp } \\
\text { - Interstitial condensation }\end{array}$ & $\begin{array}{l}\text { - Water absorption } \\
\text { - Watertightness } \\
\text { - Impact resistance } \\
\text { - Water vapour } \\
\text { permeability } \\
\text { - Release of dangerous } \\
\text { substances } \\
\text { - Hygrothermal } \\
\text { performance } \\
\end{array}$ \\
\hline 4 & $\begin{array}{l}\text { - Stable to the combined } \\
\text { stresses generated by } \\
\text { normal loads such as } \\
\text { intrinsic weight, } \\
\text { temperature, humidity, } \\
\text { and shrinkage, as well as } \\
\text { movements of the main } \\
\text { structure and wind forces } \\
\text { (suction) } \\
\text { - Avoidance of harmful } \\
\text { deformation, crack } \\
\text { formation, or loss of } \\
\text { adhesion }\end{array}$ & $\begin{array}{l}\text { - Intrinsic weight } \\
\text { - Performance on } \\
\text { exposure to } \\
\text { movements of the } \\
\text { main structure } \\
\text { - Bond/fixing strength } \\
\text { - Wind load resistance }\end{array}$ \\
\hline 6 & $\begin{array}{l}\text { - Reduction of heating and } \\
\text { air conditioning } \\
\text { - Reduction of FPV } \\
\text { temperature increase }\end{array}$ & $\begin{array}{l}\text { - Thermal resistance of } \\
\text { the system } \\
\text { - Performance or PCM } \\
\text { - Mechanical fixings }\end{array}$ \\
\hline 7 & $\begin{array}{l}\text { - Durability and service } \\
\text { life of the En- } \\
\text { ActivETICS } \\
\text { - Durability and service } \\
\text { life of components }\end{array}$ & $\begin{array}{l}\text { Temperature, } \\
\text { humidity, and } \\
\text { shrinkage } \\
\text { deformations } \\
\text { - Bond strength after } \\
\text { ageing and freeze/thaw } \\
\text { cycles } \\
\text { - Chemical and physical } \\
\text { stability } \\
\text { - Corrosion resistance }\end{array}$ \\
\hline
\end{tabular}

\subsection{ER2: Safety in case of fire}

From the fire safety point of view ETICS and EnActivETICS differ in the following aspects:

- All electrical installations, by their nature, carry some degree of fire risk. During the daylight, PV panels and cables are energised with high DC voltages;

- PV could contribute significantly to the spread of fire outside or through the construction, interferes with smoke and ventilation system of the combustion products, hinders firefighting operations, etc. [23].

The influence of PCM and FPV on fire performance shall be tested, using the test method(s) relevant to the corresponding reaction to the fire class, in order to be classified according to EN 13501-1 [24].

\subsection{ER3: Hygiene, health, and the environment}

In regard to its hygrothermal performance, the main drawback of ETICS is its single-layer protection against outdoor climate loads. Therefore, detailing of joints and openings concerning the plaster must be well designed and executed to prevent rainwater leakage [11]. It is evident that the top corners and edge as well as other corners of a building have higher outdoor climate loads dominated by wind-driven rain, while the height of a building and its location have also an impact. Critical orientation of the facade depends mainly on the dominant wind direction [25]; in the northern hemisphere the southern facade is affected by larger temperature deformations.

Another problem with the hygrothermal performance of En-ActivETICS is that the FPV is completely water vapour tight. In the case of a conventional ETICS facade system it is important to select the water vapour permeability of the base coating and finishing plaster so that no condensate can form between the base coating and insulation or between the base coating and finishing plaster. In the case of En-ActivETICS we can assume that this condensate will form behind the FPV. Even if the PCM temperature is kept relatively constant, enough water vapour will accumulate behind the PV panel (or behind the PCM, depending on the specific water vapour permeability of the PCM) over time, which can cause moisture damage. Also, the water vapour tightness of FPV does not allow the driving rain that has entered the wall or built-in moisture to dry out.

The ETAG 004 guideline refers to standard EN ISO 13788 [26] as the calculation method for hygrothermal performance. Because for En-ActivETICS (and also for ETICS) the airflow occurs through or within the element and rainwater affects the moisture conditions, EN ISO 13788 standard is not intended to be used for the assessment of the hygrothermal performance of the building envelope. More advanced dynamic simulation tools (e.g. Delphin, WUFI, etc.) should be used according to the standard EN 15026 [27]. Previous studies $[9,28]$ have well demonstrated the ability of such software to calculate the hygrothermal performance of ETICS.

The following computational analyses should be carried out in order to determine the hygrothermal performance of En-ActivETICS in different moderate and boreal climates:

- Dimensioning the sufficient cross area and length of diffusion channels between thermal insulation and PCM;

- Seeking for outdoor temperature and direct solar radiation levels below which PCM will remain in solid state;

- Calculating the efficiency gain of FPV due to thermal stabilisation of PCM as well as reduction of heat loss through the wall on diurnal as well as annual basis;

- Determining the effect of En-ActivETICS on reducing the cooling need of a building. 
In addition to computational analysis, small-scale specimen laboratory testing, climatic chamber laboratory testing as well as building scale tests of En-ActivETICS will be carried to determine its hygrothermal performance.

\subsection{ER4: Safety and accessibility in use}

There is a risk that En-ActivETICS or its components may break and fall onto pedestrians below. Big discrepancy in the temperatures between day and night or between light coloured plastered facades and dark coloured FPV, as well as the seasonal differences during a year, has necessitated developing an En-ActivETICS where normal movements of the system shall not give rise to any crack formation or loss of adhesion in the system.

Moisture accumulation behind FPV in combination with freeze-thaw cycles may weaken the bond between the base coat and rendering system as well as PCM. Therefore, the frost resistance of the base coat and plaster is highly important for En-ActivETICS, and assessment of performance based only on water absorption is not sufficient.

The following small-scale hygrothermal tests in building materials laboratory have been planned in order to study physical and mechanical properties of EnActivETICS in comparison with regular ETICS $(0,1$, and 2 layers of class-fibre reinforcement mesh in case of ETICS are included):

- Intrinsic weight of ETICS and En-ActivETICS;

- Temperature expansion and shrinking of adhesion mortar of En-ActivETICS and ETICS (base coat with finishing plaster);

- Hygric expansion and shrinking of adhesion mortar of En-ActivETICS and ETICS (base coat with finishing plaster);

- Frost resistance of adhesion mortar of EnActivETICS and ETICS (base coat with finishing plaster);

- Adhesion (perpendicular to surface to persist wind suction) and durability of En-ActivETICS mortar as well as of ETICS (between the base coat and both mineral wool and expanded polystyrene (EPS) thermal insulation);

- Resistance of ETICS to local mechanical compression (perpendicular to surface) considering both dynamic and progressive loads;

- Tensile strength (parallel to surface) of ETICS.

Both tension and deformations should be measured while testing the tensile strength of ETICS. From these, modulus of elasticity can be calculated. Further, the impact of En-ActivETICS with regard to crack formation compared to regular ETICS should be analysed.

\subsection{ER6: Energy economy and heat retention}

Differently from common ETICS, En-ActivETICS influences the energy performance of building envelopes mainly because:

- PCM behind the FPV prevents the increase of its temperature and increases the efficiency of electricity production;

- PCM behind the FPV decreases the facade temperature and hence minimises the cooling need of a building;

- Thermal energy of the PCM stored in the daytime decreases the driving potential for the heat loss during the night and therefore, leads to lower diurnal heat loss through the external wall.

It is also necessary to find out when the temperature of the PCM falls below its predetermined melting temperature in different climates.

\subsection{ER7: Sustainable use of natural sources}

Although durability assessments via visual survey or calculations have been carried out already for decades, exact prediction of degradation is complicated because of the inaccuracy of boundary conditions, materials properties, and simplification of the calculation model, as well as a variety of degradation criteria, e.g. frost attack, corrosion, mould growth, defacement, etc. [25].

A pathology field survey of 146 facades carried out in Portugal enables us to conclude that common anomalies of ETICS are related to colour/aesthetic anomalies (approximately 50\%), flatness (around 25\%), and materials rupture (also about 25\%) anomalies [29]. The most frequent causes of the anomalies (one of every six anomalies) are dirt build-up (dust), surface condensation, and rain action whereas around two out of five of the anomalies can be prevented by proper design, application, and choice of materials [29]. A solid case study, also made in Portugal, concerning cracks on joints of extruded polystyrene (XPS) suggests that only full area adhesion mortar should be used between mineral substrate and XPS thermal insulation [14]. A heat and moisture model was coupled with a thermo-mechanical finite element model (FEM) in order to assess thermal shock in coatings of EPS as well as of mineral wool, and suggestions for low Young modulus of the base coat and solar absorbance below 0.60 for the finishing layer are given [30]. A survey of building design documentation in Estonia discovered that the requirement to use certified ETICS as a whole exists in almost half of the cases and requirements for ETICS components are given only in the rest of the cases [31]. In Estonia visual degradation of ETICS was detected in facades only one to six years old with the worst condition in the area of the heaviest moisture load, i.e. in the foundation wall [32]. Damage of 51\% was classified as related to surface (except levelling), $40 \%$ to colour/aesthetics, and $9 \%$ to surface levelling [32].

The following testing in a building material laboratory is necessary to determine the durability of En- 
ActivETICS on two common thermal insulation materials - mineral wool and EPS:

- Frost durability of adhesion mortar of EnActivETICS as well as of ETICS (base coat with finishing plaster) before and after hygrothermal cycling. Durability is assessed via visual degradation by involving different moisture loads during cycling;

- Adhesion durability (perpendicular to surface to persist wind suction) of En-ActivETICS mortar as well as of ETICS (between the base coat and thermal insulation) in the case of both dry and wet substrate. Durability is evaluated via numerical results of destructive tension before and after hygrothermal cycling;

- Tensile strength (parallel to surface) of ETICS before and after hygrothermal cycling.

\subsection{Execution of the works}

Research is planned to be conducted mainly by computational analysis, laboratory tests, and buildingscale tests, all designed and analysed by using scientific methods. As a result, the studied and tested novel building envelope component will be directly applicable for actual buildings in the case of new buildings and renovation in years to come.

The performance of the En-ActivETICS concept is planned to be assessed in seven stages. Evolution of the stages and their connection to TRLs is schematically shown in Fig. 5.

In addition to the main stages, also intermediate objectives are specified:

- Development of the integration method of PCM with insulation, based on experimental techniques;

- Determination of the integration technique of FPV with the external layer of ETICS, considering FPV cells connection and electrical energy utilisation.

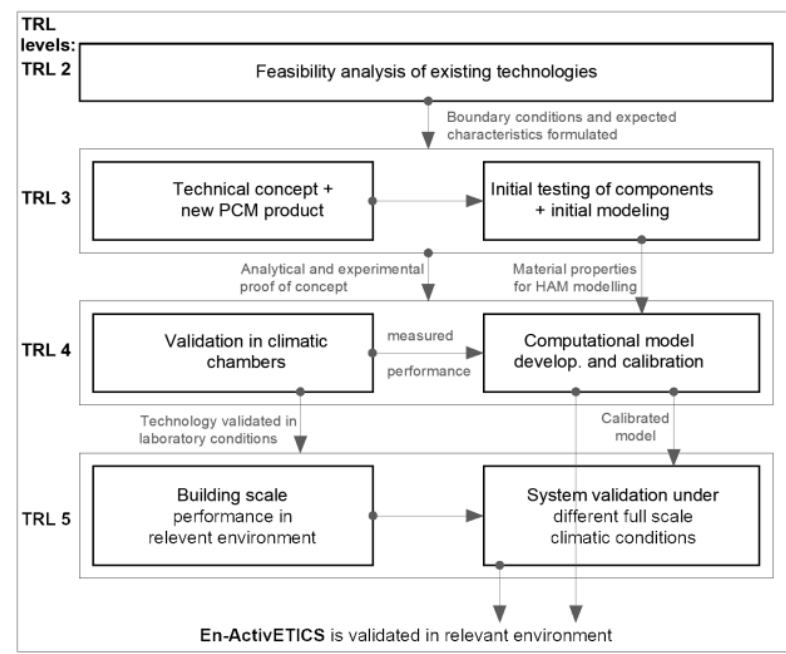

Fig. 5. Planned work stages and their connection to technology readiness levels (TRL).

\section{Discussion}

Although not much research has been carried out in this field so far, there is a potential for synergy when combining BIPV within building renovation [33]. Findings by Attoye et al. [34] indicate that BIPV facade customisation can be carried out with significant advantages such as flexibility and applicability at elemental and compositional levels. The proposed concept is intended to be more cost effective compared with traditional BIPV facades. A new external wall product that is characterised by easy application and flexibility should be developed.

Thanks to the use of PCM, the proposed solution is a new step in the development of thermal insulation material technology facilitating development of a product that can be classified as an intelligent material. As its physical characteristics are self-regulated by the application of a selected temperature range of heat storage, such material provides a high level of energy performance. Moreover, features of PCM will simultaneously contribute to the thermal regulation of the PV modules and the lower temperature of PVs will increase their efficiency. Combining aluminium fins integrated with a PCM container was considered in [35]; compared with a single flat aluminium plate, the fins gave more than $30 \mathrm{~K}$ temperature reduction. Higher electricity production of a PV/PCM system on diurnal basis compared to the reference solution without PCM was proven in [36]. The innovative character of the EnActivETICS concept is a result of research involving examination of its thermal and mechanical properties carried out in response to the technological challenge to develop a novel, cost- and material-effective way of PCM integration with FPV and thermal insulation.

The idea of thermal insulation with a latent heat accumulation potential [37] and its utilisation for stabilising PV cell temperature was theoretically analysed in [38], but it can still be considered as a highly innovative, novel approach. The main concept, product, and technology development will involve the following:

- Development of an integration technology of FPV with the external layer of ETICS instead of finishing plaster. Such a system will offer an inexpensive, flexible, moisture safe, and comprehensive facade solution;

- Development of a novel, cost- and materialeffective PCM characterised by changeable storage capacity. The effect of increased thermal mass will activate under specific temperature conditions, accumulating excessive heat gains coming from e.g. high solar radiation, which will also contribute to the lowering of the temperature of FPV and thus increase their efficiency. The material will become multifunctional, playing the role of thermal insulator, heat accumulator, and energy generator depending on the instant thermal conditions. Presently, commercially available PCM products are based on the microencapsulated paraffin, which limits the application of such materials and highly increases their cost. Direct application of pure 
paraffin will allow a significant reduction of the environmental impact, price of the system, and materials usage;

- Application of the En-ActivETICS concept should be tested using unique monitoring equipment, enabling comprehensive measurement and evaluation of the performance of the components. The test wall should be exposed to critical climatic conditions in a laboratory as well as at building scale, which makes the experiment results highly reliable and useful for further product development.

Weaknesses and threats shown in Fig. 4 reveal a need for research and development of the concept. The current paper proposes a solution for this: a method to assess and determine the performance.

Taking into account the innovative character of the novel component, the research will provide new knowledge concerning the following aspects:

- Computational performance of the proposed wall systems;

- Design procedure for industrial application;

- Energy efficiency and cost effectiveness;

- Physical behaviour under relevant exposure conditions.

It is expected that the proposed concept will contribute to the reduction of at least $15 \%$ of the heat flux during periods of high heat gains and will cover $10 \%$ of the annual electricity demand.

\section{Conclusions}

The main result of the paper is a method proposed for the assessment and determination of the performance of a novel En-ActivETICS external wall concept.

One outcome of the current paper is a literature review followed by the analyses concerning the need for a novel building envelope element. The research identifies, tests, and implements innovative ways to promote energy efficiency in buildings and fosters technologies that are ecologically friendly, economically sensible, and feasible for implementation, encouraging more sustainable energy use.

Secondly, SWOT analysis carried out indicates that the concept is competitive; however, its hygrothermal performance needs thorough analysis and testing in order to improve the reliability of the wall system. As most of the building stock in Europe built in the 1960s, 1970s, and 1980s needs energy renovation anyway, ETICS enhanced with BIPV performing efficiently with PCM has a clear advantage over traditional measures to reduce the thermal transmittance of the opaque wall.

Thirdly, the main results of the paper, i.e. the whole merit of the proposed method, are introduced. Calculations and tests needed to determine whether the novel wall system meets the essential requirements set to a building by the Construction Products Regulation are outlines. Execution of the works and their connection with TRLs in the form of a graph are introduced. By following the method, it is expected that the research will end up with a comprehensively tested and technically documented Energy Activated External Thermal Insulation Composite System, capable of adjusting its physical properties to achieve better building performance in terms of indoor environment, energy efficiency, and aesthetics.

This research was supported by the project En-ActivETICS: in a framework of M-ERA.NET by ETAG (grant No. 34/MOBERA1719029), NCBiR (grant No. MERA.NET2/2018/2/2019) \& SAS (grant No. M-ERA.NET 2 $/ 2018$ /786/En-ActivETICS), Estonian Centre of Excellence ZEBE (grant TK146), and by the personal research funding (grant PRG483), and by European Commission through the H2020 project Finest Twins (grant No. 856602).

\section{References}

1. IEA SHC TASK $56 \mid$ Building Integrated Solar Envelope Systems for HVAC and Lighting State-ofthe-Art and SWOT Analysis of Building Integrated Solar Envelope Systems (2019)

2. EPBD, Off. J. Eur. Union 30 May, (2018)

3. K. Kuusk and T. Kalamees, Build. Res. Inf. 44, 1 (2016)

4. K. Kuusk and T. Kalamees, Energy Procedia 78, 985 (2015)

5. T. Niemelä, R. Kosonen, and J. Jokisalo, Energy Build. 137, 60 (2017)

6. T. Kalamees, A. Lupišek, O. C. Mørck, A. Borodinecs, M. Aalmeida, R. Rovers, P. O. 't Veld, K. Kuusk, and S. Silva, in Cent. Eur. Towar. Sustain. Build. 2016 Innov. Sustain. Futur. CESB 2016 (2224.06.2016 Prague, Czech Republic, 2016), pp. 137144

7. V. Kukk, J. Kers, and T. Kalamees, Wood Mater. Sci. Eng. 1 (2020)

8. I. Mandilaras, I. Atsonios, G. Zannis, and M. Founti, Energy Build. 85, 654 (2014)

9. S. Ilomets and T. Kalamees, in Proc. XII Int. Conf. Perform. Exter. Envel. Whole Build. Florida, USA, December 1-5, 2013. (ASHRAE, 2013)

10. V. Kostenko, N. Gafiyatullina, G. Zulkarneev, A. Gorshkov, M. Petrichenko, and S. Movafagh, MATEC Web Conf. 73, 02011 (2016)

11. H. M. Künzel and D. Zirkelbach, in 8th Nord. Symp. Build. Phys. Nord. Ctries. 2008. Proc. (Copenhagen, June 16-18, 2008, 2008), pp. 253-260

12. E. Liisma, R. Sepri, L.-M. Raado, I. Lill, E. Witt, V. Sulakatko, and M. Põldaru, in Cent. Eur. Towar. Sustain. Build., edited by K. Hajek, P.; Tywonjak, J.; Lupišek, A.; Sojkova (Grada Publishing, a.s. for 
Czech Technical University in Prague, Prague, Czech Republic. 22-24.06.2016, 2016)

13. T. Kvande, N. Bakken, E. Bergheim, J. Thue, T. Kvande, N. Bakken, E. Bergheim, and J. V. Thue, Buildings 8, 93 (2018)

14. S. S. de Freitas and V. P. de Freitas, Struct. Surv. 34, 57 (2016)

15. G. Quesada, D. Rousse, Y. Dutil, M. Badache, and S. Hallé, Renew. Sustain. Energy Rev. 16, 2820 (2012)

16. EOTA, Guidline for European Technical Approval of External Thermal Insulation Composite Systems (ETICS) with Rendering (Brussels, 2013)

17. S. Ilomets, Renovation Need and Performance of Envelopes of Concrete Apartment Buildings in Estonia, Doctoral thesis of Tallinn University of Technology, 2017

18. P. Hoes and J. L. M. Hensen, Energy Build. 110, 79 (2016)

19. D. Heim and A. Wieprzkowicz, J. Build. Perform. Simul. 9, 542 (2016)

20. P.-R. Denz, P. Vongsignha, S. F. Haeringer2, T. E. Kuhn2, C. Maurer2, M. Hermann2, H. Seifarth2, and K. Morawietz2, Solar Thermal Facade Systems-an Interdisciplinary Approach (2018)

21. Dariusz Heim1, Ivan Chodak, Simo Ilomets, Dominika Knera, Anna Wieprzkowicz, and Targo Kalamees, in NSB 2020 12th Nord. Symp. Build. Phys. (E3S, 11-14.06.2020, Tallinn, Estonia, 2020)

22. CPR EU 305/2011, Off. J. Eur. Union. Regul. No. $305 / 201139(2011)$

23. L. Mazziotti, P. Cancelliere, G. Paduano, P. Setti, and S. Sassi, MATEC Web Conf. 46, 5001 (2016)

24. EN 13501-1, Fire Classification of Construction Products and Building Elements - Part 1: Classification Using Data from Reaction to Fire Tests (Brussels, 2019)

25. S. Vares, S. Pulakka, T. Toratti, L. Fulop, P. Hradil, E. Vesikari, A. Laitinen, A. Ruuska, T. Häkkinen, A. Tolman, S. Holøs, A. Svensson, T. S. Wester Plesser, C. King, A. Uriarte, R. Garay, F. Rodriguez, C. Tweed, and K. Gandhi, Sustainable Refurbishment of Exterior Walls and Building Facades (2012)

26. EN ISO 13788, Hygrothermal Performance of Building Components and Building Elements Internal Surface Temperature to Avoid Critical Surface Humidity and Interstitial Condensation Calculation Methods. (Brussels, Belgium, 2012)

27. EN 15026, Hygrothermal Performance of Building Components and Building Elements - Assessment of Moisture Transfer by Numerical Simulation (Brussels, Belgium, 2007)
28. A. Vašková, M. Vertal', D. Katunský, and A. Korjenic, Bauphysik 38, 378 (2016)

29. B. Amaro, D. Saraiva, J. De Brito, and I. FloresColen, J. Civ. Eng. Manag. 20, 511 (2014)

30. B. Daniotti, F. R. Cecconi, R. Paolini, G. Cocchetti, R. Galliano, and A. Cornaggia, in XIII Int. Conf. Durab. Build. Mater. Components (2014), pp. 514521

31. T. Kaus, Analysis of Building Material Selection in Construction Project Based on ETICS (in Estonian Ehitusmaterjalide Valiku Analüüs Ehitusprojektis ETICS'i Põhjal), TalTech, 2015

32. R. Sepri, Visual Analysis of Damages in the ETICS of Apartment Blocks (In Estonian - Korterelamute ETICS'is Tekkinud Kahjustuste Visuaalne Analüüs), TalTech, 2015

33. E. Saretta, P. Caputo, and F. Frontini, Sustain. Cities Soc. 44, 343 (2019)

34. D. E. Attoye, K. A. T. Aoul, and A. Hassan, Sustain. 9, 2287 (2017)

35. M. J. Huang, P. C. Eames, and B. Norton, Sol. Energy 80, 1121 (2006)

36. M. Jun Huang, Sol. Energy Mater. Sol. Cells 95, 957 (2011)

37. J. Kosny, E. Kossecka, A. Brzezinski, A. Tleoubaev, and D. Yarbrough, Energy Build. 52, 122 (2012)

38. A. Machniewicz, D. Knera, and D. Heim, in Energy Procedia (Elsevier Ltd, 2015), pp. 1684-1689 